\title{
Who persecuted the Thessalonian Christians?
}

\author{
N H Taylor \\ Department of New Testament Studies \\ University of Pretoria
}

\begin{abstract}
This article argues that the recent scholarly consensus of an essentially gentile Thessalonian church being persecuted by its gentile neighbours is founded on unsound premises. The Jewish community in Thessalonica would have had good reason to oppose Paul and the congregation he formed. The exegesis of key texts in 1 Thessalonians does not support the reconstruction of the church as composed of gentiles unconnected with the synagogue, and the ethnic background of the persecutors cannot be ascertained on the basis of the letter. The dismissal of Acts as a source of historical information is unwarranted.
\end{abstract}

\section{INTRODUCTION}

1 Thessalonians contains the earliest extant references to Christians as victims of persecution. ${ }^{1}$ According to Paul, the experience of persecution constitutes the basis of comparison between the Thessalonian Christians and those of Judaea (2:14-16). These Christian communities are alike in being victims of persecution at the hands of their compatriots, and especially in remaining faithful in the face of these external pressures. The identity of the persecutors, their motives, and the nature of the persecution inflicted have been matters of scholarly controversy.

There seems to have emerged a general consensus in scholarship that the Thessalonian church was a community of gentile Christians, and that their persecutors similarly were gentile residents of the city. This reconstruction depends on three assumptions: (1) the integrity of 2:13-16; (2) the connotations of $\sigma u \mu \phi \cup \lambda \varepsilon \tau \hat{\omega} \nu$ in $2: 14$;

\footnotetext{
${ }^{1}$ I am assuming for the purpose of this study that 1 Thessalonians dates from c $50 \mathrm{CE}$, and is earlier than Galatians, even allowing for an early date for the latter (cf Taylor 1992:45). I am assuming also that 1 Thessalonians is earlier than 2 Thessalonians (contra, Wanamaker 1990), without prejudice to the authenticity of the latter.
} 
(3) the interpretation of the reference to abandonment of idolatry in 1:9. In addition, this position requires (4) that the account of Paul's mission to Thessalonica in Ac 17:1-9 is regarded as essentially unreliable. These issues will be discussed in turn before (5) the nature of the persecution in Thessalonica can be considered.

\section{THE INTEGRITY OF 1 THESSALONIANS 2:13-16}

Paul's apparently favourable evaluation of the Judaean Christians, and the vehemence with which he expresses hostility towards the Jewish nation, have led several scholars to regard these verses as an interpolation. It is assumed that, in view of their strained relationship, Paul could not have expressed himself in positive terms on the Torahobservant churches of Judaea. Similarly, it is assumed that Paul could not have made a statement about the Jewish nation, which modern Christians would find embarrassing. There is no textual basis for positing an interpolation, but this possibility must nonetheless be considered.

Like several issues in contemporary scholarship, the interpolation theory is rooted in the Tübingen School. Baur regarded 1 Th 2:14-16 as "thoroughly un-Pauline" (1876: 87), reflecting a later period of accommodation between Jewish and gentile forms of Christianity. He argued that the reference to divine wrath in 2:16 presupposes the destruction of Jerusalem in $70 \mathrm{CE}$, and ultimately dated not merely this section but the entire letter after this date (Baur 1876:96, 340).

More recent scholars have accepted Pauline authorship of the letter as a whole, but some have argued that all or part of 2:13-16 is a post-Pauline interpolation (Pearson 1971; Koester 1982:113; Schmidt 1982; Setzer 1994:17-18). The most important recent arguments for an interpolation are those of Pearson (1971) and Schmidt (1982). Schmidt's case builds on that of Pearson, and is based on further linguistic and stylistic considerations. These have not found significant support in scholarship, largely as the sample of Paul's writings he uses is considered an inadequate basis for arguing the nonPauline authorship of 2:13-16 (Jewett 1986:40-41; Still 1999:28-35; Wanamaker 1990:33). In addition, such arguments assume that Paul's co-authors and amanuenses had no creative role in writing the letters, and that all stylistic features can be attributed to Paul himself, or rejected as non-Pauline. 
The arguments of Pearson are essentially historical and theological. He argues that the attack on the Jews for killing Christ and the prophets (2:15) is incompatible with Paul's high evaluation of his Jewish heritage and of his own accomplishments in that tradition in texts such as Gl 1:14 and Phlp 3:4-6 (1971:85). The juxtaposition of these texts, however, is fallacious, even if persecution is closely linked to both. In the Galatians and Philippians passages Paul is not so much expressing pride in his achievements in Pharisaic observance, as confessing how misguided that pride had been before his conversion, especially in that it had led him to persecute the Christians (cf 2 Cor 11:21-23; Phlp 3:4-7).

Pearson, like Baur, argues that the reference to divine wrath in 2:16 presupposes the destruction of Jerusalem and the Temple (1971:82-83). This assumes that the events of $70 \mathrm{CE}$ were the only possible catastrophe to befall the Jews which could be interpreted as divine retribution (cf Jewett 1986:37-39; Still 1999:35). The assumption is anachronistic, and takes insufficient account of the capacity of the apocalyptic mindset to interpret events of minimal or transitory significance in cataclysmic terms (cf Wanamaker 1990:117). It has been argued that Paul is referring to impending eschatological judgement rather than a historical event (Frame 1912:114; cf Best 1972:119). It has also been suggested that Paul regarded non-Christian Jews as having brought judgement on themselves for having rejected the Gospel (Gaventa 1998:38; cf Rm 1:18-32). A majority of scholars, however, argue that the text refers to a specific event, and that the recipients of the letter would have recognised the allusion (cf Best 1972:120).

Scholarly consensus dates the writing of 1 Thessalonians to c 50-52 CE (Best 1972:7-13; Jewett 1986:49-60; Kümmel 1975: 257; Robinson 1976:53; Taylor 1992:45). There is no shortage of possible events during the preceding decade to which 2:16 could arguably allude (Jewett 1971, 1986:37-39; pace Pearson 1971). Roman rule was reimposed over Judaea after the death of Agrippa I in 44 CE, and Galilee brought under direct Roman administration for the first time (Josephus, BJ 2.220; Ant 19.354-66). The rebellion of Theudas in c 46 CE was a disaster (Josephus, Ant 20.97-99), and in all probability a contributory factor to the famine in Judaea in 46-47 CE (Josephus, Ant 20.101). Malalas reports an attack by Jews on Christians in Antioch in $48 \mathrm{CE}$, leading to official intervention against the Jewish community by the Roman tribune (Chr 247:5- 
$10)^{2}$. Claudius expelled at least some Jews from Rome in 49 CE (Suet, Claud 25.4; Orosius, Hist 7.6.15-16) ${ }^{3}$. Josephus reports a massacre of worshippers in the Temple in Jerusalem in 49 CE (BJ 2.224-7; Ant 20.112).

The expulsion from Rome has perhaps become the best known of these incidents (cf Ac 18:2), and has been identified as the specific episode to which Paul refers (Bammel 1959; contra, Pobee 1985:96). This episode may have had repercussions in Diaspora communities throughout the Roman empire. Nevertheless, even if impulsore Chresto (Suet, Claud 25.4) alludes to attacks on Christians in Rome by their fellow Jews, there is no reason to suppose that Paul was in any way involved, or that this could account for hindrance of his proclamation of the Gospel to the gentiles (2:15-16). Moreover, Paul is referring in 2:14-15 to the persecution of Judaean Christians, as well as to the deaths of Jesus and the prophets which took place in Judaea. If he is alluding to a specific episode, therefore, it would seem more likely to be an event in Judaea. The massacre in the Temple is therefore the most likely known event to have been viewed by Paul as divine retribution for the offences to which he refers (cf Jewett 1986:37-38). However, the sequence of catastrophic events, culminating in the massacre in the Temple, could also have been interpreted cumulatively as representing divine judgement.

Pearson asserts that there is no evidence of persecution of Christians in Judaea before the Jewish War in 66 CE (1971:86; cf Brandon 1957:88-100). Even if the location of Paul's pre-conversion activities is disputed (Gl 1:22; cf Riesner 1998:72-73), there is strong evidence of official opposition to the Judaean Christians during the first decade of the Church (Taylor 1999, 2002), and clear indications that this escalated during and after the Caligula crisis (Taylor 1996, 2001). That this intensified further after the imposition of direct Roman rule in 44 CE has been argued by Reicke (1984), and Gl 6:12, almost contemporary with 1 Thessalonians, indicates the continuing persecution of the Judaean Christians (Jewett 1971:202-206; 1986: 38), as may Gl 4:29 (Wanamaker 1990:112-13). There is therefore strong evidence that the years immediately before 1 Thessalonians was written were a time of persecution of the Judaean churches.

2 This must be regarded as the most weakly attested of this series of events, given the late date and tendentious nature of Malalas' Chronicon. Furthermore, Malalas depicts the Jewish community as the instigators of the strife, which, if at all accurate, does not suggest their being at the receiving end.

${ }^{3}$ The date of this episode is disputed, cf. Dio, Hist 6.6. For discussion see Taylor (1992: 55). 
Paul describes the Thessalonian Christians as having become $\mu ı \mu$ таi of the Judaean churches $(2: 14)$ by virtue of having endured persecution. This has been further grounds for disputing the Pauline authorship of these verses, on account of Paul's generally pejorative attitude to the Jerusalem church reflected in the contemporaneous

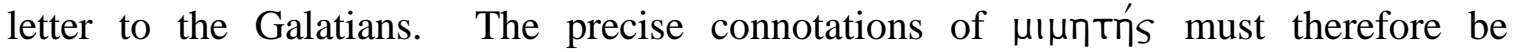
established. As well as denoting conscious and deliberate imitation of another party, the word can be used in comparison, where no imitation is implied (Michaelis 1967:664665). If Paul is using $\mu ı \mu \eta т \alpha i$ in the former sense, he is expressing unequivocal, if implied, praise for the Christian communities in Judaea. However, if Paul is merely expressing comparison between the experience of the Thessalonian Christians and that of the Judaeans, the implied praise of the latter does not imply that the Judaean Christians are a model of behaviour for the Thessalonians. There is no reason at all to believe that the Thessalonian Christians' endurance of persecution was consciously modelled on the Judaeans, or that Paul implies any form of deliberate imitation (Wanamaker 1990:112). It would seem more likely that Paul is making a comparison between the endurance of the Judaean Christians in the face of harassment from their compatriots and that of the Thessalonians (Best 1972:113; Michaelis 1967:666; Wanamaker 1990:113). Paul's implied praise for the Jerusalem church is therefore confined to regard for their perseverance in the face of persecution, and does not imply approval of their cultic observances and other specifically Jewish practices to which the Jerusalem church adhered. Still less does it imply approval of attempts to curtail the liberty of other Christians, as had recently taken place in Antioch (Gl 2:11-14; cf Taylor 1992:123-39).

Pearson's (1971:88) conclusion, that 1 Th 2:14-16 is both historically and theologically "incongruous", is unsupported by the evidence. In addition he is rightly criticised by Wanamaker (1990:31) for assuming that Romans 9-11 represents a fixed and definitive position in Paul's theology, against which such passages as 1 Th 2:13-16 can reliably be measured. 1 Thessalonians is chronologically much closer to Galatians, and, if it is to be measured against any other Pauline letter, that most contemporary with it should be the point of measurement (cf Holtz 1990b; Taylor 1992:152-70; 1997). Furthermore, judgement and redemption are not incompatible, but rather integrated, in the Jewish prophetic tradition; a dichotomy between 1 Thessalonians and Romans would 
therefore be false, as well as overlooking the judgement motif present in Romans 9-11 (cf Broer 1990: 149-59; Holtz 1990b; Staab 1969:21-22; Taylor 1997).

The arguments for an interpolation in 1 Th 2:13-16 are unconvincing, and recent scholarship has tended to accept its authenticity. (Best 1972:123; Broer 1990:137-48; Jewett 1986:36-46; Still 1999:24-46; Wanamaker 1990:29-33; cf Collins 1984:96-135). Jewett (1986:71-78) and Wanamaker (1990) have gone further in arguing that this section is essential to the structure of Paul's argument in 1 Thessalonians. While Wanamaker (1990:32-33) describes the passage as a "rhetorical digression", it is nonetheless integral to the letter, and the references to persecution need to be considered in reconstructing the situation of the Thessalonian Christians.

\section{3. $\quad \Sigma \mathrm{YM \Phi Y \Lambda ЕTH \Sigma}$}

The critical issue in interpreting $\sigma u \mu \phi \cup \lambda \varepsilon \tau \omega \hat{\nu} \nu$ in 1 Th $2: 14$ is whether or not the expression, when applied to the inhabitants of a Macedonian city, could include its Jewish population. In the case of Thessalonica, the very existence of such a Jewish community is disputed. There is no archaeological evidence of a synagogue, and only ambiguous inscriptional evidence for a Jewish population during the first half of the first century CE (Riesner 1998:344-45). However, the city has been continuously inhabited since long before the foundation of the Christian church there, which makes the survival and excavation of archaeological remains less likely than would be the case with an abandoned site. The location of Thessalonica on major land and sea routes would inevitably lead to an influx of immigrants from other parts of the Mediterranean basin (cf De Vos 1999:129-30). It is therefore "highly likely that a significant Jewish community existed at Thessalonica" at the time of Paul's mission (Wanamaker 1990:4; cf Riesner 1998:348).

While the existence of a Jewish community in Thessalonica can be surmised with some confidence, the character of the hypothetical community and its relations with its neighbours and the civic structures remain elusive (cf Riesner 1998:354). Without some knowledge of Jewish institutions and any official recognition they may have enjoyed, it is difficult both to reconstruct events in Thessalonica and to evaluate such information as is available. This applies particularly to any role the Jewish community may have played in 
inciting opposition to Paul, and in continuing harassment of the church in Thessalonica at the time 1 Thessalonians was written.

While scholars are agreed that the Thessalonian church was predominantly gentile in composition, there is less agreement as to whether the community included Jewish Christians. While some argue for an exclusively gentile church (Still 1999:69; De Vos 1999:146-47), others allow for a Jewish minority within the community (Best 1972:5). A further issue is whether the gentile Christians had any former connection with the synagogue, which will be considered in the next section. For the present this issue is important only insofar as it may indicate a motive for the Jewish community to oppose the Christian church.

Notwithstanding other possible contexts for Paul's mission to Thessalonica (Hock 1980; cf Wanamaker 1990:6-16), the possibility that he availed himself of the synagogue as a point of contact with potential converts, as recounted in Ac 17:1-4, cannot be discounted altogether. While it has been argued that there was no Jewish opposition to an entirely gentile church (Still 1999:225; De Vos 1999:158), strong motives have been identified for such opposition, should the church have originated in and separated from the synagogue. The goodwill, and even patronage, of sympathetic and eminent locals was an important component of the security of Jewish communities in Diaspora centres. Should such have been converted to Christianity, the synagogue could have lost the beneficent influence and protection of local dignitaries on which it depended (cf Riesner 1998:352). If unable to contain the Christian movement within the synagogue and its discipline and jurisdiction, the Jewish community may well have sought to suppress it entirely, or to use coercive means to reassert its authority and retain the influence of gentile patrons. Gl 5:11 attests to Paul's having been persecuted by Jews during the period immediately prior to the writing of that letter ( $\mathrm{cf} 2$ Cor 11:24). While there is no evidence that any of these episodes took place in Thessalonica, it is nonetheless clear that Paul came into conflict with established authority in Jewish communities during this period.

While a clear motive exists for opposition to Paul and persecution of the church by the Jewish community in Thessalonica, other cultic institutions may also have had reason to suppress the Christian movement. 1 Th 1:9, a text which will be discussed 
further below, would seem to indicate an absolute commitment to the Christian gospel and community on the part of Paul's converts, such as would have been unusual in Graeco-Roman cults (cf Barclay 1993:515; Donfried 1985; Still 1999:229-38; Taylor 1995). The abandonment of Graeco-Roman deities and their cults could have been perceived as threatening to incur the wrath of the gods on the city, and accordingly have been interpreted as a threat to public wellbeing (Barclay 1993:515; De Vos 1999:155-56).

Of the cults attested in Thessalonica during this period, several would have found defections to Christianity particularly obnoxious, and their patrons may have considered the church at least potentially subversive of the socio-political order (cf Donfried 1985). Refusal of Christians to participate in the Caesar cult or take imperial oaths could have been interpreted as seditious (cf Ac 17:6-7), and been grounds for persecution (Jewett 1986:123-25; Still 1999:76; Wanamaker 1990:113-4). The Christian movement may also have resembled the Cabirus cult before its institutionalisation, and appealed to the same religious needs among the lower orders of Thessalonian society, and hence have attracted the suspicion and hostility of the ruling echelon (Jewett 1986:128-32, 165-68; Wanamaker 1990:12-13). The eschatological and messianic component in Christian proclamation may have been interpreted as violation of imperial laws on astrology and divination regarding the health of the emperor (Tac, Ann 2.27-32; Riesner 1998:357).

While hostility to the Thessalonian church from both Jewish and pagan quarters can readily be understood, we need to consider which would have been more threatened by the emergence and growth of the Christian community. There is no indication that the church was of any numerical strength by the time 1 Thessalonians was written (cf De Vos 1999:154). It may therefore have been perceived as a threat by the Jewish minority before the pagan majority in the city, including the ruling cadre, became aware of it. Furthermore, the synagogue would have gathered for worship on a more regular basis than most if not all cults, and its leadership may have become aware of defections rather sooner than the guardians of the various pagan institutions with less clearly defined communities. We cannot therefore exclude the possibility that the Jewish community instigated, or at least supported, the persecution of the church in Thessalonica. To 
address this issue more closely, however, we need to consider the connotations of $\sigma \cup \mu \phi \cup \lambda \varepsilon \tau^{\alpha} ı$ in 2:14.

$\sum u \mu \phi \cup \lambda \varepsilon^{\prime} \eta \eta S$ derives from $\phi u ́ \lambda \eta$, a term used of the tribes of Israel in both the Septuagint and the New Testament, and of the corresponding entities in ancient Greek society. Blood relationships gave way to administrative, military, and political definitions at an early date (Maurer 1974:245). We should therefore understand the term in terms of fictive rather than biological kinship. No more than six occurrences of

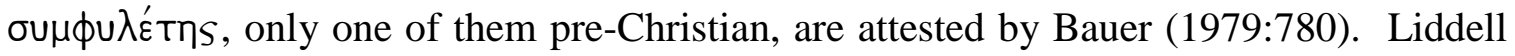
and Scott (1968:1688) cite the same pre-Christian inscription, and list a related feminine noun $\sigma u \mu \phi \cup \lambda \lambda_{i}^{\prime} \alpha$ and an adjective $\sigma u ́ \mu \phi \cup \lambda \circ$ s, each with very few attestations. This is far too small a pool on which to determine whether or not Paul uses a term with wide currency and precise meaning. In particular, it is not possible to decide on lexicographical grounds whether $\sigma u \mu \phi \cup \lambda \bar{\varepsilon}^{\prime}$ TnS would have been understood to denote the ethnic identity of the persecutors of the Thessalonian church, or whether it embraces (nonChristian) inhabitants of Thessalonica of all ethnic backgrounds.

Scholars have tended to the view that Paul is referring in 1 Th 2:14 to persecution of the Thessalonian Christians by their fellow gentiles, and that the $\sigma u \mu \phi \cup \lambda \varepsilon$ ta। are gentile residents of Thessalonica hostile to the church (Frame 1912:111; Haenchen 1971: 513; De Vos 1999:157-58). It is argued that Paul was deeply conscious of ethnicity, and that $\sigma u \mu \phi \cup \lambda \varepsilon \dot{\varepsilon} \alpha$ । therefore cannot possibly include Jews (Barclay 1993:514; Still 1999: 218-23). Paul's awareness of race, however, was far from consistent, as he is also capable of pronouncing the irrelevance of ethnic distinctions, even if their abolition has

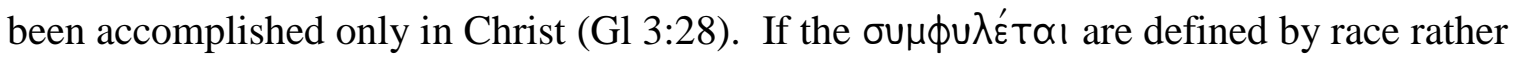
than by residence in the city, which is also arguable (Riesner 1998:352; cf Best 1972: 114), this raises further problems. It assumes that gentile Christians in Thessalonica would have been conscious of a common ethnic identity, defined in terms of not being Jewish. While the Jewish population, and Paul himself on occasion, may have perceived the demography of Thessalonica and the rest of the world in such terms, it is unlikely that other ethnic groupings in the city would have perceived their identity in similar terms. Given the cosmopolitan nature of the population of seaports on the Mediterranean (cf De Vos 1999:129-36; 144-47), it is likely that Paul attracted converts from a variety of ethnic 
backgrounds, none of whom is likely to have defined him or herself primarily in terms of not being of Jewish extraction. To define $\sigma u \mu \phi \cup \lambda \varepsilon^{\prime} \alpha_{1}$ in 2:14 in terms of not being Jewish would therefore seem to impose an inappropriate Jew-gentile dichotomy on the consciousness of the gentile residents of Thessalonica. ${ }^{4}$

The arguments to exclude the Jewish community in Thessalonica from the

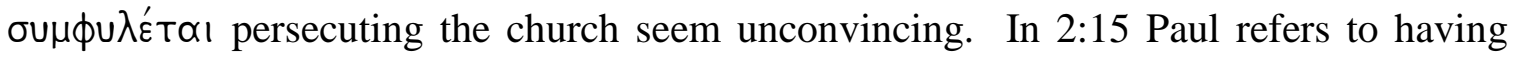
himself been persecuted by Jews, and the possibility cannot be excluded that this included an incident or incidents in Thessalonica (Malherbe 1987:62; Manus 1990:35; Wanamaker 1990:8; contra, Haenchen 1971:513). We have identified reasons why established cultic movements, Jewish and Graeco-Roman, would have had reasons to suppress the new Christian church in Thessalonica. On the basis of the evidence considered thus far, we need to recognize the possibility, if not the probability, that the synagogue may have been involved in the persecution (Frame 1912:109; Manus 1990; Wanamaker 1990:114).

\section{ABANDONMENT OF IDOLATRY}

Another argument offered for the hypothesis of an exclusively gentile church in Thessalonica, and therefore one which would have been vulnerable to persecution only from gentile sources, is 1 Th 1:9:

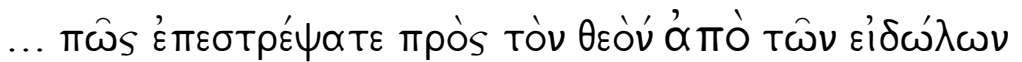

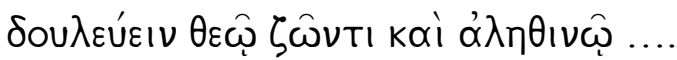

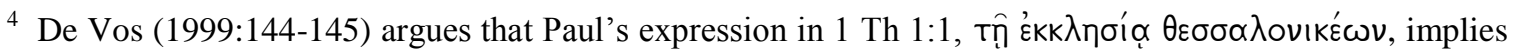
an ethnic rather than geographical identification of his addressees. His argument depends on his reconstruction of the population of Thessalonica as overwhelmingly Macedonian (De Vos 1999:129). He does not argue for an ethnically homogeneous population, however, and allows for minorities from elsewhere (De Vos 1999:130). While it is possible that the population of Thessalonica could have had a sense of common ethnic identity which was not defined in terms of being "non-Jewish", the church is likely to have attracted converts from marginalised ethnic minority communities. Such Christians are not likely to have viewed those persecuting them as compatriots in an ethnic sense, or to have identified themselves as "Thessalonians" in terms of common ethnic identity with the majority of the population of the city. De Vos's argument depends also on comparisons with the opening addresses in Paul's other undisputed letters, which are clearly geographical in their identification of the addressees. However, Paul's other undisputed letters, with the possible exception of Galatians, were all written later than 1 Thessalonians. It therefore cannot be assumed that Paul had established a clear and invariable custom in this regard by the time 1 Thessalonians was written.
} 
There can be no doubt that the $\varepsilon^{\prime} \delta \omega^{\prime} \lambda \alpha$ are the objects of pagan devotion, to whom the true and living god is contrasted. Nor can there be any doubt that Paul regards the god of the Christians as the god of the Jews also. At first sight, therefore, the argument that this verse cannot refer to Jewish Christians would seem incontrovertible, as would its corollary that the Thessalonian church consisted exclusively of gentiles (cf Best 1972:82; De Vos 1999:144-47).

That the church was predominantly of gentile extraction, and of previously pagan religious disposition, would seem clear (Frame 1912:87; Wanamaker 1990:4, 85). The case for an exclusively gentile, formerly pagan, composition of the Thessalonian community, on the basis of this verse, is not as clear as would at first sight seem to be the case.

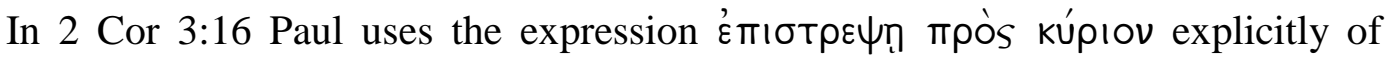
Jews, albeit not with an accompanying reference to idolatry. In Gl 4:8-11 he makes similar reference to the conversion from paganism of the Galatian Christians, but suggesting that judaising practices would constitute a relapse to their former ways (Betz 1979:218; Dunn 1993:225; Longenecker 1990:182). Irrespective of whether the Galatian churches included Jewish members (cf Dunn 1993:223; Riesner 1998:349), Paul was clearly capable of associating some Jewish observances with paganism, even if only for rhetorical effect, and even if stopping short of labelling Jewish worship of God in such terms.

Perhaps more significantly for the interpretation of 1 Th 1:9, Paul makes reference

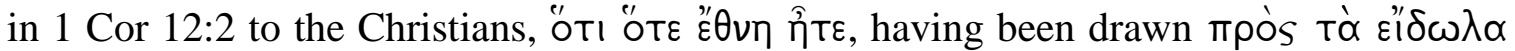
$\tau \grave{\alpha} \alpha$ $\phi \omega v \alpha$. This is significant in that it is generally accepted that the Corinthian church included Jewish as well as gentile converts (cf 1 Cor 1:22-23; 7:18). Paul would therefore seem to make generalised statements about the former lives of his converts, which do not apply to each individual in the community. Alternatively he addresses a specific section of the community, rather than the church as a whole, at some points in his letters (Barrett 1968:278; Soards 1999:253; cf Conzelmann 1975:205; Horsley 1998:168). It should therefore not be assumed on the basis of 1 Th 1:9 that all the Thessalonian Christians were gentiles who had formerly participated in pagan cults. 
A factor which seems not to have been duly considered is the nature of the devotional life of those commonly labelled "godfearers". The assumption that the majority of Paul's converts had been "pagan" (Wanamaker 1990:4; cf Holtz 1990a:61; Staab 1969:15), inferring on the basis of 1:9 that they were non-godfearing gentiles, whom Paul had not reached through the synagogue (Wanamaker 1990:7-8; contra Still 1999:68-69), would seem to assume that all godfearers had abandoned paganism altogether. Godfearers were by definition not fully converted to Judaism and

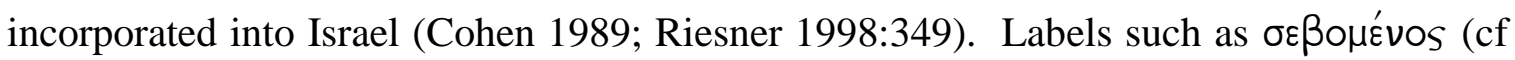

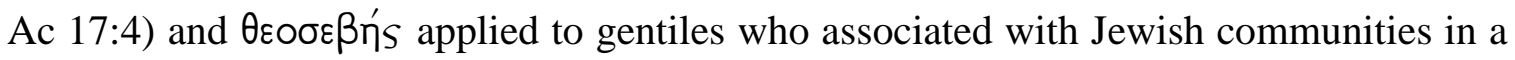
variety of ways, which did not necessarily involve abandonment or repudiation of other cultic associations and practices (Cohen 1989). While the label is a Jewish category, those to whom it is applied are nonetheless classified as gentiles (cf Barrett 1998:812). It cannot therefore be assumed that godfearers in Thessalonica would have been Jewish in all but name and foreskin.

1 Th 1:9 therefore cannot be used to substantiate a thesis that the Thessalonian church consisted largely or entirely of gentiles who had no previous links with the synagogue. Even if Holtz's contention, that the language of 1 Thessalonians would have been comprehensible to gentiles only if they were acquainted with the synagogue (1990a: 10), cannot be substantiated, our reconstruction of the Thessalonian church must allow for the presence of godfearing gentiles who had not fully abandoned pagan worship. We therefore cannot exclude the possibility that the Jewish community reacted to their conversion by seeking to suppress the church and to re-establish synagogue jurisdiction and a clear distinction between Jews and gentiles.

Arguments on the basis of the text of 1 Thessalonians have been shown to be inconclusive. We turn now to the account in Acts, before reaching any conclusions.

\section{THE ACTS ACCOUNT OF PAUL'S MISSION TO THESS- ALONICA}

Scholarly opinions on the historical reliability of Acts are sufficiently well known to require no repetition (cf Taylor 1992:49-51). So far as the account of Paul's mission in Thessalonica is concerned, there are specific problems raised by commentators on both 
Acts and 1 Thessalonians. These concern apparent incompatibilities between the Acts account and information found in 1 Thessalonians and elsewhere. While the account of the mission, and Paul's subsequent flight, is in itself plausible, it is not entirely consistent with information deriving directly from Paul (Haenchen 1971:510; cf Best 1972:5).

Some of the assumptions founded on 1 Thessalonians have been addressed in the sections above. These concern the composition of the church as reflected in the letter, compared with the mission account in Acts 17 and the synagogue as the locus of Paul's preaching. The texts on the basis of which Paul's preaching in the synagogue in Thessalonica has been disputed have been shown to provide far from conclusive evidence that the church was composed (almost) entirely of gentiles with no previous link with Judaism or the synagogue.

A major objection to the plausibility of the Acts account is the assumption that, if Paul preached in the synagogue on three Sabbaths (Ac 17:2), then the mission was of no more than three or four weeks' duration. 1 Thessalonians, it is argued, reflects a more well-established Christian community than would have been possible had Paul's time in Thessalonica been so brief. It is also argued that Phlp 4:15-16 requires a longer mission in Thessalonica, given its distance from Philippi and the time required to travel between these centres (Best 1972:5; Haenchen 1971:510; Wanamaker 1990:7). While the last point would at first sight seem incontrovertible, a closer look at the Acts text is required.

Fitzmyer divides the periscope of Paul's mission to Thessalonica into three parts (1998:593): Ac 17:1-4, arrival and synagogue preaching; 5-9, reaction of the Jews; 10-15, flight. It is the first two parts which are of concern for the present purpose. There is a clear break between v 4 and v 5, which could suggest that Luke derives vv1-4 and vv 5-9 from different sources. While there is an obvious sequential link between the two parts, there is no requirement that the events beginning in $\mathrm{v} 5$ followed immediately upon the third Sabbath sermon in the synagogue in vv 1-4. The Acts account is "condensed" (Wanamaker 1990:7), and allows for a continued mission outside the synagogue before the reaction of the Jewish community escalated into public opposition such as that described in vv 5-9 (cf Fitzmyer 1998:593). Nor does the Acts narrative exclude the possibility of points of contact with potential converts other than the synagogue, such as workplaces (cf Hock 1980:37-42). 
According to Ac 17:5 public opposition to Paul was incited by zealous Jews, and escalated into mob action ultimately leading to official action by the civic authorities. This account is questioned chiefly on the grounds that the narrative fits a Lukan paradigm, and that Jews would not have concerned themselves with the spread of an exclusively gentile movement (Still 1999:225). This premise has been found to be unsubstantiated, and we have found good reason to believe that the Jewish community would have been concerned at the spread of Christianity in Thessalonica. The full incorporation into the church of those who had been peripheral to the synagogue would have challenged the boundaries of Judaism, and have risen political as well as religious

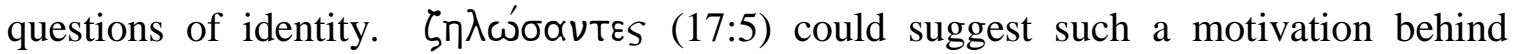
Jewish attempts to suppress the Christian movement (cf Barclay 1993: 516-18), in addition to the social and political considerations identified in preceding sections. This could be corroborated by Paul's allusion to being persecuted in G1 5:11, where he implies that circumcision, and by extension the distinction between those inside and outside the Covenant, is precisely the issue.

That Christian proclamation in Thessalonica was fundamentally shaped by Jewish apocalyptic eschatology is apparent from the language and imagery employed in 1 Thessalonians, and this is reflected in allusions in the Acts narrative (17:2-3, 6-7). The connotations of political subversion attributed to Paul's preaching (6-7) reflect manipulation of eschatological motifs (cf Donfried 1985:342-52; Still 1999:77-78). This is not to deny that elements in the synagogue may have found common purpose with the

adherents and patrons of other cults, which could explain how an intra-Jewish conflict became a matter of public concern. Nevertheless, it is likely that opposition to Paul and the church began, as the Acts narrative suggests, with a Jewish group which articulated its objections to Christian proclamation in a manner which incited hostility in other sections of the population in Thessalonica.

\section{THE PERSECUTION IN THESSALONICA}

Hostility to the church did not end after Paul's departure. It may well be that complete separation of church from synagogue led to a diminution in the role of the Jewish 
community in the persecution. Notwithstanding any psychological stress which the Christians may have suffered (Malherbe 1987: 48), the evidence for external pressures on the community is overwhelming (Barclay 1993; Still 1999; De Vos 1999:155-60). Conflicting interests of other cultic movements and of civic allegiance, identified above (cf Still 1999:229-38, 251-66), may have brought official action against the church. In addition to concerted persecution of the community as a whole, consideration needs to be given to pressures which Christians may have sustained from within their previous social networks. The exclusivity of Christian allegiance, unlike that required of adherence to pagan cults or even to the synagogue (Cohen 1989; cf Taylor 1995), would have strained family and kinship relationships (cf Still 1999:230, 251-55) as well as having other consequences in an urban economy in which paganism impinged upon every social and economic activity (cf Still 1999:232-38).

In conclusion, we have found good reason to believe that hostility to Paul and the Christian community in Thessalonica originated within the Jewish community, but became a matter for civic attention before Paul left the city. Pressures on the community continued after Paul's departure, but it is possible that complete separation of church from synagogue led in time to a diminution in the role of the Jewish community in the persecution. Hostility would have continued from quarters where Christians were or had been in close relationships of social and economic dependence, and in contexts where their allegiance to civic and imperial deities and institutions was challenged.

\section{Works consulted}

Bammel, E 1959. Judenverfolgung und Naherwartung zur Eschatologie des ersten Thessalonischerbriefs. ZThK 56, 294-315.

Barclay, J M G 1993. Conflict in Thessalonica. CBQ 55, 512-30.

Barrett, C K 1968. The first epistle to the Corinthians. Peabody, MA: Hendrickson.

Barrett, C K 1998. Acts. Edinburgh: T \& T Clark.

Bauer, W et al 1979. A Greek-English Lexicon of the New Testament and other early Christian literature. Chicago: University of Chicago Press.

Baur, F C 1876. Paul: The apostle of Jesus Christ. London: Williams \& Norgate. 
Best, E 1972. A commentary on the first and second epistles to the Thessalonians. London: Black.

Betz, H D 1979. Galatians. Philadelphia: Fortress.

Brandon, S G F 1957. The fall of Jerusalem and the Christian Church. London: SPCK.

Broer, I 1990. "Der ganze Zorn ist schon über sie gekommen”: Bemerkungen zur Interpolationshypothese und zur Interpretation von 1 Thess 2,14-16, in Collins, $\mathrm{R}$ F (ed), The Thessalonian Correspondence, 137-159. Leuven: Peeters.

Cohen, S J D 1989. Crossing the boundary and becoming a Jew. HTR 82, 13-34.

Collins, R F 1984. Studies on the first letter to the Thessalonians. Leuven: Leuven University Press.

Conzelmann, H G 1975. 1 Corinthians. Philadelphia: Fortress.

Donfried, K P 1985. The cults of Thessalonica and the Thessalonian correspondence. NTS 31, 336-56.

Dunn, J D G 1993. The epistle to the Galatians. Peabody, MA: Hendrickson.

Fitzmyer, J A 1998. The Acts of the Apostles. New York: Doubleday.

Frame, J E 1912. The epistles of St Paul to the Thessalonians. Edinburgh: T \& Clark.

Gaventa, B R 1998. First and second Thessalonians. Louisville: John Knox Press.

Haenchen, E 1971. The Acts of the Apostles. Philadelphia: Westminster.

Hock, R F 1980. The social context of Paul's ministry. Philadelphia: Fortress.

Holtz, T 1990a. Der erste Brief an die Thessalonicher. Neukirchen-Vluyn: Neukirchener Verlag.

Holtz, T 1990b. The judgement on the Jews and the salvation of all Israel: 1 Thess 2,1516 and Rom 11,25-26, in Collins, R F (ed), The Thessalonian Correspondence, 284-294. Leuven: Peeters.

Horsley, R A 1998. 1 Corinthians. Nashville: Abingdon.

Jewett, R 1971. The agitators and the Galatian congregation. NTS 17, 198-212.

Jewett, R 1986. The Thessalonian Correspondence. Philadelphia: Fortress.

Koester, H 1982. Introduction to the New Testament. New York: De Gruyter.

Kümmel, W G 1975. The New Testament. London: SCM.

Liddell, H G, Scott, R \& et al 1968. A Greek-English Lexicon. Oxford: Clarendon.

Longenecker, R N 1990. Galatians. Waco: Word. 
Malherbe, A J 1987. Paul and the Thessalonians. Philadelphia: Fortress.

Manus, C U 1990. Luke's account of Paul in Thessalonica, in Collins, R F (ed), The Thessalonian Correspondence, 27-38. Leuven: Peeters.

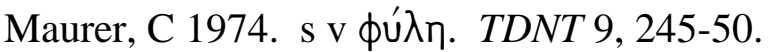

Meeks, W A 1983. The first urban Christians. New Haven: Yale.

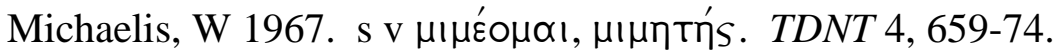

Pearson, B A 1971. I Thessalonians 2.13-16: A deutero-Pauline interpolation. HTR 64, 79-94.

Pobee, J S 1985. Persecution and martyrdom in the theology of Paul. Sheffield: JSOT.

Reicke, B I 1984. Judaeo-Christianity and the Jewish establishment, AD 33-66, in Bammel, E \& Moule, C F D (eds), Jesus and the politics of his day, 145-152. Cambridge: CUP.

Riesner, R 1998. Paul's early period. Grand Rapids: Eerdmans.

Robinson, J A T 1976. Redating the New Testament. London: SCM.

Schmidt, D D 1982. 1 Thess 2:13-16: Linguistic evidence for an interpolation. JBL 102, 269-279.

Setzer, C J 1994. Jewish responses to early Christians. Minneapolis: Fortress.

Soards, M L 1999. 1 Corinthians. Peabody, MA: Hendrickson.

Still, T D 1999. Conflict in Thessalonica. Sheffield: Sheffield Academic Press.

Staab, K 1969. Die Thessalonicherbriefe. Regensburg: Pustet.

Taylor, N H 1992. Paul, Antioch and Jerusalem. Sheffield: Sheffield Academic Press.

Taylor, N H 1995. The social nature of conversion in the early Christian world, in Esler, P F (ed), Modelling early Christianity, 128-136. London: Routledge.

Taylor, N H 1996. Palestinian Christianity and the Caligula crisis. JSNT 41, 101-124; $42,13-41$.

Taylor, N H 1997. Paul, Pharisee and Christian: Israel, the gentiles, and the law of Moses in light of cognitive dissonance theory. Theologia Viatorum 24, 45-65.

Taylor, N H 1999. Jerusalem and the temple in early Christian life and teaching. Neotestamentica 33, 245-60.

Taylor, N H 2001. The temptation of Jesus on the mountain: A Palestinian Christian polemic against Agrippa I. JSNT 83, 27-49. 
Taylor, N H [2002]. Stephen, the temple, and early Christian eschatology. Revue Biblique 47. (Forthcoming.).

De Vos, C S 1999. Church and community conflicts. Atlanta: Scholars.

Wanamaker, C A 1990. The epistles to the Thessalonians. Grand Rapids: Eerdmans. 